the great want of classifications to guide us in the direction most promising for the prevention of tuberculosis.

Feb. 13th, 1905 . I am, Sirs, yours faithfully,

HUGH R. BEEVOR.

\section{FORMOLYPTOL IN DIPHTHERIA.}

\section{To the Editors of 'THE LANCET.}

SIRs,-About two months ago a note was published in THE LANCET on the successful use of mulyptol locally for diphtheria and a week or so after that I was called to see a child, aged 11 years, whom I found complaining of her throat which her mother said had been sore for 12 hours. She had a temperature of $104 \cdot 4^{\circ} \mathrm{F}$. and both tonsils and the back of the fauces were covered with a thick ashy-grey membrane. I had already sent a child from the family above (it was a tenement house) into the South Devon Hospital for tracheotomy with what proved laryngeal diphtheria and I was told that another child had died in the house from "acute bronchitis." I endeavoured to get some mulyptol but could only get formolyptol, which I used as a spray and also a gargle, besides administering two-minim doses internally. The temperature subsided in 24 hours, the throat cleared up rapidly, and the child was out of all danger in less than two days. Dr. W. L. Pethybridge, pathologist to the hospital, kindly made a culture from a swab and found the diphtheria bacillus. I was most agreeably surprised at the efficacious and rapid way in which the formolyptol acted and hope this note may be useful to those who may have to treat a similar condition.

I am, Sirs, yours faithfully,

$$
\text { C. E. RUSSEL RendLe, }
$$

Feb. 11th, $1905 . \quad$ Assistant Surgeon, South Devon Hospital.

\section{COFFEE AND SEWAGE.}

\section{To the Editors of THE LANCET.}

SIRs,-Your editorial remarks on the recent decision of Mr. Chapman in the case of the coffee salvaged from the s.s. Caravellas are evidently made upon the basis of a very imperfect report of the evidence and are, therefore, I venture to think, a little unfair. I feel sure that I can appeal to your well-known justice to all parties for a hearing so that the facts may be better understood than they have been.

At the hearing of the case I produced evidence and specimens to show: 1 . That coffee during roasting attains a temperature of about $180^{\circ} \mathrm{C}$, or $356^{\circ} \mathrm{F}$, which is maintained for a long time. 2. That before reaching this it remains for a considerable time at or near $100^{\circ}-103^{\circ} \mathrm{C} .\left(212^{\circ}-218^{\circ} \mathrm{F}\right.$.), during which time much vapour of water is given off. 3 . That after a period of rest or even slight fall of temperature this again advances; various oils and acid products, together with water from the breakdown of the berry by heat, are given off and the berry swells and softens. Its loss in weight is from 15 to 20 per cent. on the dry coffee. 4. The sanitary officials admitted that organisms, pathogenic or not, would not survive this heat coupled with the vapours present. 5. Carefully made cultivations were made from the coffee received from the roasters in the roasted state and no growth of any kind ensued. The roasted berries were quite sterile. It was suggested that toxins produced by the organisms might be present but no evidence of their existence was before the court and I need not enlarge on the improbability of their presence in the roasted coffee.

I also venture to deprecate the use of the term "sewage soaked." I am informed that the ship was sunk between Coalhouse Point and Cliffe, some two miles below Gravesend. The water is no doubt contaminated but it is not fair to call it "sewage." If every bag of sugar, chest of currants, bag of wheat, \&c., that got well wetted by such water were condemned there would be enough for the sanitary officers to do. But such things, it is well known, are not stopped, though sugar at least, which is used as often as not without cooking, is far more dangerous than green coffee. It was the fact that it had heated and showed signs of mould that caused the seizure. The sewage suggestion appeared to be an afterthought.

Pray understand that my remarks apply only to the particular lot of 60 tons with which I dealt. I saw no specimens of that condemned elsewhere and express no opinion on their state. It is obvious that green coffee wetted with perfectly good water would ferment and rot in time. $\quad \mathrm{I}$ am, Sirs, yours faithfully,

Feb. 11th, 1905.

R. J. FrISWELL,

** Mr. Friswell is, of course, entitled to his opinion but we may remind him that pollution is not necessarily of a bacteriological kind. The water of the river at the points mentioned is in his own words "no doubt contaminated," whether it be fair or not to call it sewage, and the coffee had been admittedly soaked in this water. No one, we imagine, would relish the idea of drinking water polluted with sewage effluent even if sterile.-ED. L.

\section{CURRENT THEORIES OF THE HEREDT- TARY PROCESS. \\ To the Editors of THE LANCET.}

SIRS,-In the annotation on the above subject in The LANCET of Feb. 4th, p. 307, the following statement occurs :-

Both these writers [Boveri and Delage] have shown that denucleated eggs produceil by mechanical extrusion of nuclei can be fertiliset in the sea urchin and that they give rise to normal blastulæ, gastrulæ, and larva. Hence the "determinants" of heredity are present in the cell body of the egg.

Surely this is a false conclusion, since no notice is taken of the nucleus of the spermatozoon. The fact that if fertilisation is effected by alien spermatozoa the resulting larvæ show purely paternal characters is a very strong argument in favour of Weisınann's view that the nucleus is the vehicle of hereditary transmission. There is no evidence in these experiments that the cytoplasm of the ovum plays any part at all in the transmission of hereditary characters. I am, Sirs, yours faithfully,

St. Thomas's Hospital, Feb. 7th, 1905.

Charles Powell White.

** From the experiments referred to two entirely opposite conclusions are drawn-viz, that attributed to Professor W. F. R. Weldon, F.R.S., in our issue of Feb. 4th, and that to which Mr. Powell White alludes above. These interpretations are still the subject of discussion. Boveri himself admits that the "merogonie" experiments are equivocal because bastard larvæ, arising by the union of an entire egg with the spermatozoon of a distinct species, may also present the pure paternal form. At the same time, referring to the criticism raised by Pfeffer and others that the spermatozoon is an entire cell and not merely a nucleus, he points out that this argument is not admissible in appraising the part played by the egg protoplasm in fertilisation. In bastard larvæ which have obtained nuclear substance only from the spermatozoon in the fertilisation of egg fragments without nucleus ("merogonie") the paternal type appears exclusively ( $v$ ide Boveri : "Ergebnisse ueber die Konstitution des Zellkerns," Jena, 1904, pp. 104, 105).-ED. L.

\section{COUGH DUE TO INTESTINAL WORM.}

To the Editors of THE LANCET.

SIRs,-The extraordinary case of reflex lumbrical irritation contributed to THE LANCET of Jan. 28th by Mr. Prosper St. Leger Liston reminds me of a somewhat similar pathological picture painted by the father of one of my patients in the first half of the last century. There is one striking difference however; for the main figure in the sketch, by Dr. R. J. Graves of Dublin, to which I allude, was a Tænia instead of an Ascaris lumbricoides, otherwise the title of Mr. Liston's case would have served for that of Dr. Graves. The latter physician was not as fortunate as the former he did not make out his case but suffered the humiliation of being "scored off" by an unqualified lady doctor.

Dr. Graves's case was one of "severe cough and loss of weight due to tapeworm in the intestine." The details are much too instructive to be lost. A young woman attacked with symptoms of violent and alarming "bronchitis" was attended by a friend of Dr. Graves. When seen by the latter he found that the fits of coughing went on for hours with extraordinary intensity. The cough was dry, noisy, 